\title{
Impact of Altitude and Seasons to Volume, Brix Content, and Chemical Composition of Aren Sap in North Sulawesi
}

\author{
Herdianto Lantemona ${ }^{1}$, Abdul L. Abadi ${ }^{2}$ Arief Rachmansyah ${ }^{3}$, Julius Pontoh ${ }^{4}$ \\ ${ }^{1}$ Doctoral Program, Faculty of Agriculture Brawijaya University, Malang 65145 East Java, Indonesia and; \\ Faculty of Industrial Technology, Minaesa Institute of Technology, Jl. Stadion Selatan Walian-Tomohon, 95439, \\ North Sulawesi \\ ${ }^{2}$ Faculty of Agriculture Brawijaya University, Malang 65145 East Java, Indonesia \\ ${ }^{1}$ Faculty of Engineering, Brawijaya University, Malang 65145 East Java, Indonesia \\ ${ }^{4}$ Faculty of Mathematics and Natural Sciences, Sam Ratulangi University, Manado, North Sulawesi, Indonesia
}

\begin{abstract}
The aim of the paper is to describe the impacts of altitude and season to volume, Brix contents, and chemical composition of Arenga pinnata sap (Aren sap) from North Sulawesi Province, Indonesia. The Aren sap was collected from Aren population growing in different altitudes. The samples of Aren population growing at altitude 0-100 $\mathrm{m}$ asl were collected from North Minahasa district, the samples of Aren population growing at altitude $100-500 \mathrm{~m}$ asl were collected from Minahasa District, and the samples of Aren population growing at altitude from altitude $>500 \mathrm{~m}$ asl were collected from Tomohon District. In every study site, Aren sap was collected two times in a year, once during dry season and the other during rainy season. The result of the study shows that altitude provides significant impacts to sap production. There is a significant difference on brix content among Aren sap which was tapped from different altitudes and seasons. Seasons ultimately contribute to protein content. There is no significant difference on the phosphorus content between sap which was harvested from different altitudes and seasons. Seasons and altitude provide a significant impact on Magnesium and Calcium content in sap. Altitudes significantly affect Potassium content.
\end{abstract}

Keywords - Aren sap, biodiversity, bioenergy, physical environment, sap minerals

\section{INTRODUCTION}

Recent crises on global energy have led into effort in energy exploration, seeking for more sustainable and environmental friendly sources of energy. It is particularly relevant with the trend of increasing fossil fuel consumption and global warming [1]. Exploring and producing alternative sources of energy has emerged as one of interesting topics for research and discussion among scholars. Hydrogen, biodiesel, alcohol, methane, wind energy, and geothermal have all been discussed as world's potential renewable sources of energy which would replace the long-used fossil-fuel energy. The uses of renewable forms of energy are one of the key for sustainable development [2]. In such discussion, bioethanol receives a lot of attention. Scholars argue that bioethanol is one of the potential energy alternatives, which are expected to be able to supply continuous need of energy. Bioethanol can be produced from plant biomass which is abundance in all part of the earth. Bioethanol technically is produced from plant's biomass fermentation [3], [4].

Carbohydrates as a basic material for bioethanol production is found to be abundant in plant tissues, ranging from plant's tubers, leaves, to steam [5]. According to John et. al. (2011), the abundance of macro and micro algae on the earth also provides opportunities for bioethanol production [6]. These plants are sources of carbohydrates from aquatic ecosystems. Plants sap, a liquid which can be found in the xylem and phloem of plant, has also been reported to contain glucose which can be fermented into alcohol [7]. These all means that plants principally are rich in term of raw material for bioethanol production [8], [9].

Arenga pinnata (Arenga Palm, locally called Aren Palm) is one of the potential palm trees which have been identified as potential sources for bioethanol production [10]. Arenga pinnata is a native palm species to Malesian regions, ranging from wet tropical rain forests to dry forests. In Indonesia, it is reported to grow in many places. From the point of view of ethnobotanical, it is argued that many parts of the plants organs such as leaves, bark, flower, fruits and buds have been used for numerous applications. Traditionally, the technology to produce bioethanol has been practiced by many indigenous people in Indonesia through nira fermentation. Nira is the natural sap that comes from Arenga palm. Compared to the other crops to produce bioethanol, Arenga palm offers numerous advantages. Arenga palm grows and is abundant in the wild environment, yet without having significant management practices. There are no intensive agriculture practices needed to maintain 
maximum production of the sap. The sap of such species can be harvested and taped in both dry and rainy seasons. Importantly, Arenga palm is not considered as one of the food materials, and therefore is able to minimize debates on the uses of Aren to produce bioethanol. It is particularly important since recently there have been increasing conflicts on the use of cassava, sugar cane, maize and other plants with high content of carbohydrates as a raw material for bioethanol production [11]. This advantage provides additional opportunities to the uses of Aren sap as a potential source for bioethanol production.

North Sulawesi, Indonesia, principally is a habitat for Arenga pinnata. In North Sulawesi, the population of A. pinnata is abundant and can be found in many habitat types, from lowland to highland ecosystems. In its natural habitat, Arenga palm grows as a solitary individual plant with a trunk diameter reaching $30-40 \mathrm{~cm}$. A. pinnata is one of the important components of traditional agroforestry in North Sulawesi. Traditionally, the local people of North Sulawesi tap Aren's sap to produce palm sugar. Aren sap principally can be converted into bioethanol, but so far, research and development of bioethanol in such regions is poor. The quality of the sap, however, varies according to environment. It is widely reported that the environment where Arenga pinnata grows affects sugar, protein, and mineral contents of the plant.

As far, few studies have been implemented to generate basic data and information related to the environmental impacts on Aren sap quality and quantity. This becomes the limitation on the management of Aren sap production and processing to become bioethanol in North Sulawesi. The aim of the paper is to describe the impact of altitudes and seasons to volume, sugar contents and chemical composition of Arenga pinnata sap (Aren sap) from North Sulawesi Province, Indonesia.

\section{MATERIALS AND METHODS}

The area and ecosystem of North Sulawesi are diverse, ranging from lowland to mountain ecosystem. According to statistical data, wild Aren population grows spreading from lowland to mountain forests. In this study, sap was collected from different altitudes. The first sap sample group was collected from Arenga palm growing at 0-100 $\mathrm{m}$ asl. In such environment, Aren sap was collected from three villages namely Kaima, Lansot and Kaburukan in North Minahasa. The second sap sample was collected from Arenga palm growing at 100-500 m asl. In this second site, Aren sap was tapped from Kali Village, Minahasa Regency. The third sap sample group was collected from Arenga palm growing at $>500 \mathrm{~m}$ asl. In such cluster, sap was collected from Rok-rok, Lahendong and Tara-tara villages in Tomohon District.

In each cluster site, Aren sap was collected in two seasons, namely dry season and rainy season. In dry season, Aren sap was tapped from September to October, while in rainy season Aren sap was taped from January to February. In each cluster, 12 mature individuals of Arenga palm were selected. The mature individual shared the characteristics of (1) palm trunk diameter c.a. $30-60 \mathrm{~cm}$, (2) plant height was more than $8 \mathrm{~m}$, and (3) palm individually had produced flowers called inflorescence.

Aren's inflorescence was cut and sap was tapped and collected in a sterile container. Tapping was stopped after 12 hours and sap liquid was transferred into the laboratory for further chemical contents analysis. The total volume of sap which was produced from individual sample was measured using $1000 \mathrm{ml}$ beaker glass. In the laboratory, about $1 \mathrm{ml}$ of sap liquid was dripped onto the well of Brix meter. The displayed number shown by the Brix meter was recorded as a value of sap sample brix content.

During the next step, about $600 \mathrm{ml}$ sap from different locations was transferred into $1000 \mathrm{ml}$ beaker glass. For each location, experimental sample was replicated by 5 . These samples were boiled until the Brix content reached about 20\%. Samples were cooled and prepared for the content analysis on Protein, Phosphorus, Calcium, Magnesium and Potassium. Determining the crude protein in Aren sap was done using MacroKjeldahl method. Technically, this method consists of three standard steps including sample digestion in sulfuric acid, distillation of the ammonia, and quantification of the ammonia. The Phosphor content in Aren was measured using Spectrophotometry technique. The Calcium, Magnesium and Potassium were analyzed using atomic absorption spectrophotometer (AAS) methods. Data of Aren sap volume, Brix, protein, Phosphorus, Calcium, Magnesium and Potassium content were analyzed by Analysis of Variance (ANOVA). The advance significance test was assessed by Tukey's HSD test.

\subsection{Aren sap volume comparison}

\section{RESULT AND DISCUSSION}

Based on the results of the statistical analyses, the impact of altitude to sap volume was found to be significant. There was, however, no significant impact of season and season-altitude factors to sap volume productions (Table 1). It has been mentioned by scholars that temperature is one of the main determinant factors of plant productivity, distribution and survival. For instance, the highest place affect plant metabolism and therefore alter some key metabolism processes in plant [12]. 
Table 1.Impact of different altitudes and seasons to sap volume

\begin{tabular}{|l|l|l|}
\hline Environmental variables & $\mathrm{F}_{\text {test }}$ & Sig F \\
\hline Altitude & 53.116 & 0.000 \\
\hline Season & 3.608 & 0.062 \\
\hline Altitude*Season & 0.033 & 0.967 \\
\hline
\end{tabular}

The variety of sap volume tapped in different seasons and altitudes was given in Table 2 . Based on the Tukey test, the highest volume was produced from wild Aren palm population growing at $>500 \mathrm{~m}$ asl. In such altitude, and in both seasons, (rainy and dry) the means of production reached $22.54 \mathrm{~L} /$ tree/day; while in the lowest place ( $0-100 \mathrm{~m}$ asl), in both seasons the production of Aren sap was the lowest (c.a. $8.91 \mathrm{~L} /$ tree/day). Aren sap is the fluid that contains water, mineral, proteins and nutrients. So far, there is no scientific information on the sap volume productivity concerning altitudes and seasons. It seems that the altitude of $>500 \mathrm{~m}$ asl would become the most suitable place for maximum production of Aren sap.

Table 2. The comparison of Aren sap volume tapped in different seasons and altitudes

\begin{tabular}{|c|c|c|}
\hline Season & $\begin{array}{c}\text { Altitude } \\
(\mathrm{m} \text { asl })\end{array}$ & $\begin{array}{c}\text { Aren sap volume (liter) } \\
\text { Mean } \pm \text { SD }\end{array}$ \\
\hline Dry & $0-100$ & $7.98 \pm 3.62$ \\
& $100-500$ & $17.00 \pm 5.95$ \\
& $>500$ & $21.58 \pm 4.44$ \\
\hline Wet & $0-100$ & $9.85 \pm 3.30$ \\
& $100-500$ & $19.50 \pm 6.03$ \\
& $>500$ & $23.50 \pm 4.01$ \\
\hline
\end{tabular}

\subsection{Brix content}

Brix is usually used to estimate sugar content, which is accumulated in plant tissues. The impact of weather in glucose productions among several plants has been reported by many authors. Zheng et. al. (2012) observes that abiotic component such as temperature, sun radiation, precipitation and humidity contributes an important role in plant metabolism [13]. The ANOVA test confirms that there was significant difference on brix content among Aren sap tapped from different altitudes and seasons (Table 3).

Table 3.Impact of altitudes and seasons to Brix content

\begin{tabular}{|l|l|l|}
\hline Environmental variables & $\mathrm{F}_{\text {test }}$ & Sig F \\
\hline Altitude & 7.016 & 0.004 \\
\hline Season & 6.666 & 0.016 \\
\hline Altitude*Season & 27.173 & 0.000 \\
\hline
\end{tabular}

The highest content of brix (15.66\%) was produced from Aren population growing at $0-100 \mathrm{~m}$ asl and harvested in dry season. The lowest content $(12.64 \%)$ was recorded at Aren sap growing at $>500 \mathrm{~m}$ asl and harvested in rainy season (Table 4). These data show that seasons and altitudes contribute to brix content in sap. Zheng et al., 2012 in their research confirms that principally the amount of Glucose Sea on buckthorn berries was influenced by weather [13].

Table 4. Brix content Aren sap tapped in different seasons and altitudes

\begin{tabular}{|l|c|c|}
\hline \multicolumn{1}{|c|}{ Season } & $\begin{array}{c}\text { Altitude } \\
(\mathrm{m} \text { asl })\end{array}$ & $\begin{array}{l}\text { Brix content }(\%) \\
\text { Mean } \pm \text { SD }\end{array}$ \\
\hline Dry & $0-100$ & $15.66 \pm 0.66$ \\
& $100-500$ & $14.60 \pm 0.49$ \\
& $>500$ & $13.53 \pm 0.58$ \\
\hline Wet & $0-100$ & $14.51 \pm 0.30$ \\
& $100-500$ & $13.61 \pm 0.51$ \\
& $>500$ & $12.64 \pm 0.50$ \\
\hline
\end{tabular}

Note: Mean values marked in different superscript are significantly different.

A place with high altitude is often correlated with low temperature compared to the lowland areas. Temperature provides a significant impact on the other abiotic factors, including rain, humidity, sun intensity and wind speed [12]. In almost all biota and living systems, temperature provides a direct impact to enzyme activities. In dry season, the maximum radiation leads to the high activities of enzyme and therefore leads to the high metabolism rates. In rainy season, the sunlight is often less maximum and photosynthesis can be said to be less 
maximum as well. In relation to the metabolism aspect, this condition will become the limiting factor for photosynthesis to produce sugar. In dry season, there is often optimal sunlight that provides energy for photosynthesis to produce sugar [14], [15].

\subsection{The comparison of protein}

Besides sugar, sap derived from palms trees has been identified to contain Amino acids, minerals, and vitamins [16]. In Arenga, several kinds of proteins have also been identified. Statistical analysis shows that seasons ultimately contribute to protein content. Conversely, there is no significant difference in protein content in the altitude-season interaction as well as altitude factors (Table 5).

Tabel 5.Impact of altitude and season to protein content

\begin{tabular}{|c|c|c|}
\hline Environmental variables & $\mathrm{F}_{\text {test }}$ & Sig F \\
\hline Altitude & 0.782 & 0.469 \\
\hline Season & 9.916 & 0.004 \\
\hline Altitude*Season & 4.760 & 0.018 \\
\hline
\end{tabular}

Based on the Tukey test, the highest protein content was produced by sap which was collected in dry season at $100-500 \mathrm{~m}$ asl. In such situation, the protein content was about $0.75 \%$. The lowest protein was found at sap which was collected from $100-500 \mathrm{~m}$ asl in rainy season. In such situation, the protein produced was about $0.28 \%$ (Table 6). Different seasons provide different temperature condition and therefore provide different impacst on the rate of metabolism. These would contribute a significant impact to plant's protein production. In this study, it seems that the highest protein content at Aren sap in dry season was correlated with sugar content from Aren sap. Protein is synthesized in plant as a principal unit as enzymes and macromolecules. As a physiological mechanism, protein syntheses depend on the plant environment. Scholars point out that environmental stress contributes to modification in genes expression, and therefore brings such impacts on enzymes [17]. Enzymes are a crucial component in plant metabolism.

Table 6. Protein content of Aren sap which were tapped in different seasons and altitudes

\begin{tabular}{|c|c|c|}
\hline Season & $\begin{array}{c}\text { Altitude } \\
(\mathrm{m} \text { asl })\end{array}$ & $\begin{array}{c}\text { Protein content }(\mathrm{ppm}) \\
\text { Mean } \pm \text { SD }\end{array}$ \\
\hline Dry & $0-100$ & $0.50 \pm 0.18$ \\
& $100-500$ & $0.75 \pm 0.13$ \\
& $>500$ & $0.61 \pm 0.09$ \\
\hline Rainy & $0-100$ & $0.45 \pm 0.17$ \\
& $100-500$ & $0.28 \pm 0.17$ \\
& $>500$ & $0.53 \pm 0.24$ \\
\hline
\end{tabular}

\subsection{Phosphorus comparison}

Statistical analyses confirm that there is no significant difference on the Phosphorus content between Nira liquid harvested from different altitudes and seasons (Table 7). The percentage of Phosphorous was quite low in Aren sap. Phosphor is a crucial component in plant for many metabolism purposes. Deficiency of phosphor has been recognized as the cause of decreasing crop production significantly. Scholars point out that the most crucial factor of phosphor deficiency is related to the phosphor availability in soil [18]. Altitudes and seasons, therefore, are not significant to phosphor metabolism.

Table 7.Impact of altitudes and seasons on Phosphorus content in Aren sap

\begin{tabular}{|c|c|c|}
\hline Environmental variables & $\mathrm{F}_{\text {test }}$ & Sig F \\
\hline Altitude & 1.167 & 0.328 \\
\hline Season & 4.167 & 0.052 \\
\hline Altitude*Season & 3.167 & 0.060 \\
\hline
\end{tabular}

Many authors have reported phosphorus as a crucial element in plant structure, but its existence in plant exudates is poorly known. In plant, phosphor is found in nucleic acid and is rarely found in liquids or plants exudates. Phosphorus in plant exudates was firstly reported by Tolbert and Wiebe in 1955 [19]. According to Vance et al. (2003), the concentration of phosphor in plants range from 0.05 to 0.50 percent of the plant dry 
Impact of altitude and seasons to volume, Brix content, and chemical composition of Aren sap in

weight [20]. Compared to such standard, the Phosphor content in sap was quite low (Table 8), but it doesn't mean that the plant was undergoing Phosphor deficiency.

Table 8. Phosphorus contents of Aren sap in different seasons and altitudes

\begin{tabular}{|c|c|c|}
\hline Season & $\begin{array}{c}\text { Altitude } \\
(\mathrm{m} \text { asl })\end{array}$ & $\begin{array}{c}\text { Phosphor }(\%) \\
\text { Means } \pm \text { SD }\end{array}$ \\
\hline Dry & $0-100$ & $0.002 \pm 0.004$ \\
& $100-500$ & $0.000 \pm 0.000$ \\
& $>500$ & $0.000 \pm 0.000$ \\
\hline Rainy & $0-100$ & $0.000 \pm 0.000$ \\
& $100-500$ & $0.004 \pm 0.005$ \\
& $>500$ & $0.008 \pm 0.008$ \\
\hline
\end{tabular}

\subsection{Magnesium comparison}

Seasons and altitudes as environmental variables provide such a significant impact on Magnesium (Table 9). According to Wilkinson et al. (1990), the concentration of Magnesium in plant is influenced by Magnesium saturation in soil [21]. Magnesium is a vital macronutrient for plant growth and metabolism. In healthy plants, magnesium percentage must be about $0.1-0.8 \%$ of the dry weight of plant biomass [22].

Table 9.Impact of altitudes and seasons to Magnesium content in Aren sap

\begin{tabular}{|l|l|l|}
\hline Environmental variables & $\mathrm{F}_{\text {test }}$ & Sig F \\
\hline Altitude & 3.862 & 0.035 \\
\hline Season & 10.733 & 0.003 \\
\hline Altitude*Season & 3.821 & 0.042 \\
\hline
\end{tabular}

The Tukey test confirms that the highest Magnesium was produced in rainy season at population growing at $>500 \mathrm{~m}$ asl. In such environment, about $4.00 \mathrm{ppm}$ of Magnesium was produced. Conversely, the lowest Magnesium (c.a. $2.15 \mathrm{ppm}$ ) was produced in the altitude $>500 \mathrm{~m}$ asl (Table 10). Magnesium provides a significant impact on photosynthesis. In rainy season, however, the rate of photosynthesis is quite low, and therefore the consumption of $\mathrm{Mg}$ is also low. Natural decomposition of brotite, dolomite, and olivine rock releases Magnesium to the soil which is absorbed by plants roots.

Table 10. Magnesium comparison of Aren sap

\begin{tabular}{|l|l|c|}
\hline Season & $\begin{array}{c}\text { Altitude } \\
(\mathrm{m} \text { asl })\end{array}$ & $\begin{array}{c}\text { Magnesium content }(\mathrm{ppm}) \\
\text { Means } \pm \text { SD }\end{array}$ \\
\hline Dry & $0-100$ & $2.20 \pm 0.41$ \\
& $100-500$ & $2.67 \pm 0.32$ \\
& $>500$ & $2.15 \pm 0.32$ \\
\hline Rainy & $0-100$ & $2.30 \pm 0.24$ \\
& $100-500$ & $3.56 \pm 0.69$ \\
& $>500$ & $4.00 \pm 1.67$ \\
\hline
\end{tabular}

Based on the previous survey of Magnesium in 25 plant samples using spectro-photometry and flame photometry, Basta and Tabatabai (1985) conclude that the average of total Magnesium calculated is about 0.327 and 0.331. Magnesium was absorbed in the ionic forms [23]

4.6. The comparison of Calcium

Statistically, altitudes and seasons provide a significant impact on calcium content in sap (Table 11).

Table 11.Impact of altitudes and seasons to calcium content

\begin{tabular}{|l|l|l|}
\hline Environmental variables & $\mathrm{F}_{\text {test }}$ & Sig F \\
\hline Altitude & 9.693 & 0.001 \\
\hline Season & 348.917 & 0.000 \\
\hline Altitude*Season & 9.706 & 0.001 \\
\hline
\end{tabular}


The Tukey test confirms that highest calcium content was found at sap which was harvested in 0-100 m asl and was tapped in dry season. In such case, the calcium calculated was about $2.70 \mathrm{ppm}$. The lowest content of calcium was found at population growing at $100-500 \mathrm{~m}$ asl tapped in rainy season (0.00 ppm). Soil in humid region often has limited amount of Calcium. Moreover, the sandy soil with $\mathrm{pH}$ less than 5.0 often contributes to the deficiency of calcium. The highest Calcium content was found in dry season, compared to the rainy season (Table 12). The highest content of Calcium was found at altitude $>500 \mathrm{~m}$ asl, and decreased in line with decrease in altitude. These data are similar with the trend of Brix content. Basta and Tabatabai (1985) state that Calcium value among 25 plants, which are examined by spectro-photometry and flame photometry, are 1.20 and $1.19 \%$ [23]. In another study, Taji et al., (1993) calculate Calcium content in dry weight of plant which is about $0.2-3.5 \%[22]$

Table 12.Calcium content of niraAren

\begin{tabular}{|l|c|c|}
\hline Season & $\begin{array}{c}\text { Altitude } \\
(\mathrm{m} \text { asl })\end{array}$ & $\begin{array}{c}\text { Calcium content }(\mathrm{ppm}) \\
\text { Means } \pm \text { SD }\end{array}$ \\
\hline Dry & $0-100$ & $2.70 \pm 0.39$ \\
& $100-500$ & $2.19 \pm 0.61$ \\
& $>500$ & $1.48 \pm 0.25$ \\
\hline Rainy & $0-100$ & $0.01 \pm 0.01$ \\
& $100-500$ & $0.00 \pm 0.00$ \\
& $>500$ & $0.01 \pm 0.01$ \\
\hline
\end{tabular}

\subsection{Potassium content}

Potassium contributes significantly to increase crop production through the root growth and development, enzyme system activation, reduction on respiration and, thus, energy loss prevention. In plant metabolism, potassium also increases protein content. The potassium in Nira sap liquids could become an indicator for plant metabolism performance in different environmental settings. Altitudes significantly affect potassium content. However, there is no significant difference in term of season-altitude interaction (Table 13).

Table 13. Impact of altitudes and seasons to Potassium content

\begin{tabular}{|c|c|c|}
\hline Environmental variables & $\mathrm{F}_{\text {test }}$ & Sig F \\
\hline Altitude & 32.786 & 0.000 \\
\hline Season & 1.245 & 0.276 \\
\hline Altitude*Season & 2.280 & 0.124 \\
\hline
\end{tabular}

The Tukey test confirms that places located at $0-100 \mathrm{~m}$ asl produced the highest potassium $(4.27$ $\mathrm{ppm}$ ) and the lowest was produced at the population growing at $>500 \mathrm{~m}$ asl. (2.17 ppm) (Table 14). Zubair et al. (2006) provides evidence that potassium contributes significantly in pre-flowering growth of Gladiolus grandiflorus. Both phosphor and potassium in certain level was reported to play an important role in plant growth and metabolism in Kenaf.

An experiment conducted by Basta and Tabatabai in 1985 on the Potassium value in 25 plants using spectro-photometry and flame photometry confirmed that potassium value in plants were 3.08 and $3.07 \%$ [23] . According toTaji et al. (1993), potassium in plant ranges from $0.5-6 \%$ of the dry weight of the plant [22].

Table 14. Potassium content at Aren sap

\begin{tabular}{|c|c|c|}
\hline Season & $\begin{array}{c}\text { Altitude } \\
(\mathrm{m} \text { asl })\end{array}$ & $\begin{array}{c}\text { Potassium content }(\mathrm{ppm}) \\
\text { means } \pm \text { SD }\end{array}$ \\
\hline Dry & $0-100$ & $4.29 \pm 0.01$ \\
& $100-500$ & $2.16 \pm 0.10$ \\
& $>500$ & $2.23 \pm 0.07$ \\
\hline Rainy & $0-100$ & $4.25 \pm 0.04$ \\
& $100-500$ & $4.25 \pm 0.04$ \\
& $>500$ & $2.10 \pm 1.49$ \\
\hline
\end{tabular}

\section{CONCLUSION}

The impact of altitudes to sap volume was significant. The highest volume of Aren sap was produced by the population growing at $>500 \mathrm{~m}$ asl. There is a significant difference on brix content among Aren sap which was tapped from different altitudes and seasons. The highest brix content (15.66\%) was found at sap produced by Aren palm growing at $0-100 \mathrm{~m}$ asl in dry season. Seasons ultimately contribute to protein content. The highest protein $(0.75 \%)$ of Aren Sap was produced by Aren population growing at $100-500 \mathrm{~m}$ asl 
when sap was collected in dry season. There is no significant difference on the phosphorus content between Nira liquid which harvested from different altitudes and seasons. Seasons and altitudes as environmental variables provide a significant impact on Magnesium. The highest content (c.a. $4.00 \mathrm{ppm}$ ) of Magnesium was found in sap which was collected in rainy season at $>500 \mathrm{~m}$ asl. Altitudes and seasons provide a significant impact on calcium content in sap. The highest calcium content was found at sap harvested in $0-100 \mathrm{~m}$ asl and tapped in dry season. In such case, the calcium was calculated to be about $2.70 \mathrm{ppm}$. The lowest content of calcium was found at population growing at $100-500 \mathrm{~m}$ asl which was tapped in rainy season. Altitudes significantly affect potassium content. Population growing at $0-100 \mathrm{~m}$ asl produces the highest potassium $(4.27 \mathrm{ppm})$ and the lowest was produced at the population which growing at $>500 \mathrm{~m}$ asl $(2.17 \mathrm{ppm})$.

\section{REFERENCES}

[1] A.F. Alhajji and J.L Williams, Measures of petroleum dependence and vulnerability in OECD countries, Middle East Economic Survey, 46(16), 2003, 21-28.

[2] I. Dincer, Renewable energy and sustainable development: a crucial review, Renewable and Sustainable Energy Reviews, 4(2), 2000, $157-175$.

[3] A. Demirbas, Biofuels securing the planet's future energy needs, Energy Conversion and Management, 50(9), 2009, $2239-2249$.

[4] M. Balat and Balat, Recent trends in global production and utilization of bio-ethanol fuel, Applied Energy, 86(11), 2009, $2273-2282$.

[5] M.O. Dias, M.P. Cunha, C.D. Jesus, G.J. Rocha, J.G.C. Pradella, C.E. Rossell and A. Bonomi, Second generation ethanol in Brazil: Can it compete with electricity production?, Bioresource technology, 102(19), 2011, 8964-8971.

[6] R.P. John, G.S. Anisha, K.M. Nampoothiri, and A. Pandey, Micro and macroalgal biomass: a renewable source for bioethanol, Bioresource Technology, 102(1), 2011, 186-193.

[7] D. Barh and B.C. Mazumdar, Comparative nutritive values of palm saps before and after their partial fermentation and effective use of wild date (Phoenix sylvestris Roxb.) sap in treatment of anemia, Research Journal of Medicine and Medical Sciences, 3(2), 2008, $173-176$.

[8] H.L. Chum and R.P. Overend, Biomass and renewable fuels, Fuel processing technology, 71(1), 2001, $187-195$.

[9] J.S. Yuan, K.H. Tiller, H. Al-Ahmad, N.R. Stewart and C.N. Stewart Jr, Plants to power: bioenergy to fuel the future, Trends in plant science, 13(8), 2008, 421-429.

[10] D.S. Effendi, Prospek Pengembangan Tanaman Aren (Arenga pinnata Merr) Mendukung Kebutuhan Bioetanol di Indonesia, Perspektif, 9, 2010, 36-46.

[11] L.H. Ziska, G.B. Runion, M. Tomecek, S.A. Prior, H.A. Torbet and R. Sicher, An evaluation of cassava, sweet potato and field corn as potential carbohydrate sources for bioethanol production in Alabama and Maryland, Biomass and bioenergy, 33(11), 2009, 1503-1508.

[12] A.L. Angert, Growth and leaf physiology of monkey flowers with different altitude ranges. Oecologia, 148(2), 2006, $183-194$.

[13] J. Zheng, B. Yang, M Trépanier and H . Kallio, Effects of genotype, latitude, and weather conditions on the composition of sugars, sugar alcohols, fruit acids, and ascorbic acid in sea buckthorn (Hippophaë rhamnoi des ssp. mongolica) berry juice, Journal of agricultural and food chemistry, 60(12), 2012, 3180-3189.

[14] W. Larcher, Photosynthesis as a tool for indicating temperature stress events, In E.D. Schulze (Ed) Ecophysiology of photosynthesis (Springer Berlin Heidelberg1994) 261-277.

[15] L. Hendrickson, M.C. Ball, J.T. Wood, W.S. Chow and R.T. Furbank, Low temperature effects on photosynthesis and growth of grapevine, Plant, Cell \& Environment, 27(7), 2004, 795-809.

[16] A. Kosugi, R. Tanaka, K. Magara, Y. Murata, T. Arai, O. Sulaiman and Y. Mori, Ethanol and lactic acid production using sap squeezed from old oil palm trunks felled for replanting, Journal of bioscience and bioengineering, 110(3), 2010,322-325.

[17] M.M. Sachs and T.H.D. Ho, Alteration of gene expression during environmental stress in plants, Annual review of plant physiology, 37(1), 1986, 363-376.

[18] J.L. Zhen, J. Yuan, H. Zhang, Z. Li, X. Bai, X. Chen, W. Zhang, and F. Zhang, Phosphorus Dynamics: From Soil to Plant, Plant Physiology, 156, 2011, 997-1005

[19] N.E. Tolbert and H. Wiebe, Phosphorus and sulfur compounds in plant xylem sap, Plant Physiology, 30(6), $1955,499-504$.

[20] C.P. Vance, C. Uhde-Stone and D.L. Allan, Phosphorus acquisition and use: critical adaptations by plants for securing a non renewable resource, New Phytologist, 157(3), 2003 423-447.

[21] S.R. Wilkinson, R.M. Welch, H.F. Mayland and D.L. Grunes, Magnesium in plants: uptake, distribution, function, and utilization by man and animals, 1990.

[22] A.M. Taji, W.A. Dodd, R.R. Williams, Plant tissue culture practice (Armidale, NSW: University of New England, 1993).

[23] N.T. Basta and M.A. Tabatabai, Determination of total potassium, sodium, calcium, and magnesium in plant materials by ion chromatography, Soil Science Society of America Journal, 49(1), 1985, 76-81. 